\title{
Integrasi Pesantren pada Sistem Pendidikan Formal di Sekolah Dasar Negeri (SDN)
}

\author{
Umi Musya'adah \\ STAI Taruna Surabaya \\ Email : umimusya1989@gmail.com
}

\begin{abstract}
This study aims to see how Islamic boarding schools apply the totality of education by relying on exemplary, environment and habituation through various tasks and activities. So that all what children see, hear, feel and do is education. In the midst of globalization, people are increasingly individualistic and materialist, so education oriented to character values is needed. In this context, the pesantren has succeeded in educating its students with these character values. School is a place where students experience a process of socialization, and influence children to conform (adapt) to prevailing norms. During the first years of children entering school, the school emphasizes the importance of the control function more than other functions. therefore there should be an integration of pesantren into the formal education system in public elementary schools (SDN).
\end{abstract}

Keywords: integration, Islamic boarding schools, public elementary schools (SDN)

\section{Pendahuluan}

Setelah beberapa lama terjadi dikotomi pendidikan pesantren dan sekolah umum di Indonesia, pemerintah mulai kebingungan melihat maraknya problematika sosial, degradasi moral, rendahnya sikap nasionalisme, dan hilangnya nilai-nilai substansi dalam pendidikan di sekolah umum. Yang paling memprihatinkan tentu moral anak-anak sekolah umum yang kian hari kian merosot, apalagi dengan sekolah di rumah by daring selama pandemic covid 19 ini. Anak-anak bisa dengan sangat mudah mengakses internet dan banyak sekali tanpa pendampingan orang tuanya. Anak-anak awalnya menyampaikan ke orang tua nya kalau ada sekolah online, tetapi kalau tidak ada control dari orang tua, anak-anak akan dengan mudah bergaul dengan siapapun dengan gadgednya, banyak sekali kenakalan anak-anak terjadi saat ini karena mereka berselancar tanpa batas di dunia internet. 
Hari ini, Pendidikan formal dan dan non formal (pesantren) adalah dua lembaga pendidikan yang mempunyai banyak sekali perbedaan. Pendidikan umum dalam hal ini, SD (Sekolah Dasar) mempunyai keunggulan dari segi rasionalitas dan eksperimentasi. Sedangkan pesantren menurut Azyumardi Azra ialah dunia tradisional Islam yang mewarisi dan memelihara continuitas tradisi Islam yang dikembangkan oleh para ulama dari masa ke masa, dan tidak terbatas pada periode tertentu dalam sejarah islam. ${ }^{1}$ Secara historis, pesantren tidak saja mengandung makna keislaman, tetapi juga keaslian Indonesia. Seperti yang di ungkapkan Nur Cholis Madjid, pesantren merupakan lembaga pendidikan Islam yang memiliki watak indigenous yang ada sejak kekuasaan HinduBudha dan formulasinya juga dapat diakui ketika Islam berusaha mengadaptasikan (mengislamkan)-nya. ${ }^{2}$

Sementara Zamakhsyari Dhofier ${ }^{3}$ Martin Van Bruinessen ${ }^{4}$, dan Hanun $^{5}$ mengatakan bahwa pesantren adalah model pendidikan Islam yang diadopsi dari sistem pendidikan yang ada di Timur Tengah sejak dahulu. Sedangkan menurut Abdurrahman Wahid, bentuk dan sifat pesantren pada waktu itu, adalah sebagai lembaga pendidikan agama (tafaqquh fi al-din), sosial keagamaan, dan penyiaran agama, islam dengan corak ajarannya yang fiqih-sufistik dengan orientasi ukhrawiyahnya. ${ }^{6}$ Dari sini dapat disimpulkan bahwa pesantren sebagai pendidikan adalah " proses adopsi" sistem pendidikan Timur Tengah dan sekolah Hindu-Budha di pulau Jawa. Sistem pendidikan pesantren disamping menyerap elemen-element yang ada pada sistem pendidikan Islam Timur Tengah, juga menyerap element-element sistem pendidikan dan keagamaan Hindu-Budha. Manifestasi corak ajaran yang fiqih-sufistik tersebut, membawa santri berprilaku sakral pada kehidupan sehari-hari dan kepekaan yang luar biasa terhadap kejadian-kejadian yang berkaitan dengan hukum agama yaitu halal dan haram,pahala dan

${ }^{1}$ Azyumardi Azra, Pendidikan Islam: Tradisi Dan Modernisasi Menuju Millenium Baru (Jakarta: Logos, 2002),107.

${ }^{2}$ Nur cholis Madjid, Bilik-Bilik Pesantren Sebuah Potret Perjalanan (Jakarta: Mizan Paramadina, 1988), 25.

${ }^{3}$ Zamakhsari Dhofier, Tradisi Pesantren, Study Tentang Pandangan Hidup Kyai (Jakarta: LP3ES,1982)

${ }^{4}$ Martin Van Bruinessen, Kitab Kuning: Pesantren dan Tarekat (Bandung: Pustaka 1995),153.

5 Hanun Asrohah mengatakan bahwa sistem pendidikan pesantren memiliki ciri-ciri yang sama dengan sistem madrasah, zawiyah, dan halaqah di timur tengah. Baca Hanun Asrohah,, Kelembagaan Pesantren Asal-Usul Dan Perkembangan Pesantren Jawa (Jakarta; Bagian proyek peningkatan informasi penelitian dan diklat keagamaan, 2004)1993.

${ }^{6}$ Abdurrahman Wahid, “ Asal Usul Tradisi Keilmuan Di Pesantren” Jurnal Pesantren (Oktober-Desember 1984), 7. 
dosa dan sebagainya, sehingga dapat menimbulkan pribadi yang peka terhadap hal-hal yang bersifay ukhrawi, dan kurang peka terhadap hal-hal yang bersifat duniawi.

Malik Fajar menggambarkan adanya perbedaan antara tradisi pendidikan di pesantren dan pendidikan formal di sekolah dasar, ia mengatakan bahwa tradisi pesantren memiliki keunggulan dari segi moralitas tetapi minus dari segi rasionalitas, meskipun melahirkan pribadi yang tangguh secara moral, tetapi lemah secara intelektual. Sebaliknya pendidikan formal mempunyai keunggulan dari sisi rasionalitas dan ditambah pengayaan di bidang skill, tetapi minus pengayaan moral. Dalam kenyataanya pendidikan formal hanya menghasilkan manusia yang cerdas tetapi kurang mempunyai kepekaan etika dan moral. ${ }^{7}$ Oleh karena itu sudah saatnya dicarikan usaha untuk mengintegrasikan antara pesantren dan pendidikan formal sejak dini yaitu di tingkat sekolah dasar, sehingga dapat tercipta suatu kesatuan antara moralitas dan rasionalitas.

Pesantren dikenal sebagai lembaga pendidikan tradisional yang terasimilasikan dari sebuah budaya yang ada di Indonesia. ${ }^{8}$ Dan kemudian pesantren dikenal secara akrab karena dengan adanya elemen di dalamnya sebagai ciri dari pesantren itu sendiri yaitu adanya seorang kiai, ustad, santri, masjid/mushola, dan pembelajaran kitab kuning di dalamnya. Pesantren adalah tempat para santri beraktifitas seperti belajar, tidur dan mengadi kepada seorang kyai (mecari barakah kyai)dan terdapat pula mushola atau masjid sebagai sarana beribadah, terkadang juga pesantren diartikan sebagai gabungan kata sant (manusia baik) dengan suku kata tra (suka menolong), dan sehingga kata pesantren bisa diartikan sebagai tempat pendidikan manusia baik-baik. ${ }^{9}$ Lebih rinci lagi dijelaskan oleh Strenberk dalam Yasin bahwa ada dua pendapat mengenai pesantren, pertama pesantren berasal dari Indonesia sendiri, yang dikaitkan dengan budaya Hindu-

\footnotetext{
${ }^{7}$ Ahmad Barizi (ed), Holistik Pemikiran Pendidikan Malik Fadjar (Jakarta: Raja Grafindo Persada, 2005), 219220.

Hal ini bisa ditelusuri dari ciri pesantren yang berbentuk asrama karena bentuk asrama sendiri telah diterapkan oleh agama Budha sebelum Islam datang, lihat dalam Hanun Asrohah, Sejarah Pendidikan Islam, 144. Dalam makalah lain yang ditulis pula oleh Hanun Arohah menceritakan bahwa ada beberapa teori yang membentuk adanya pesantren, yakni pertama asimilasi budaya Hindu-Budha yakni seperti dalam pemakaian santri, kedua diadopsi dari Timur Tengah seperti pemakaian pembelajaran kitab kuning, ketiga warisan budaya Hindu-Budha seperti sistem pesantren yang berasrama, hubungan guru dan murid, dan sifat pesantren yang jauh dari keramaian, Lihat kembali dalam Hanun Asrohah, Lembaga Pendidikan Islam Tradisional di Indonesia; Makalah Sejarah Sosial Pendidikan Islam, (Surabaya:IAIN-Sunan Ampel), 6

${ }^{9}$ Lihat dalam Manfred Ziemek dalam Wahjoetomo, Perguruan Tinggi Pesantren, Ibid, 70
} 
Budha yang kemudian diadobsi oleh Islam sebagai peralihan fungsi, ${ }^{10}$ kedua pesantren yang didasari atas sepenuhnya dari Islam sendiri, pendapat ini didasari atas ciri-ciri pesantren yang ditemukan sama pada masa Rasulullah SAW. ${ }^{11}$

\section{Integrasi Pesantren Kedalam Sistem Pendidikan Di Sekolah Dasar}

Integrasi berasal dari bahasa Inggris “integration” yang berarti kesempurnaan atau keseluruhan. Poerwadarminto mengartikan integrasi adalah penyatuan supaya menjadi kebulatan unsur yang saling berbeda dalam kehidupan masyarakat, sehingga menghasilkan pola kehidupan masyarakat yang memiliki keserasian fungsi. ${ }^{12}$ Dalam konteks pendidikan, integrasi ilmu agama dan ilmu umum sebenarnya sudah pernah dilakukan oleh M. Natsir . dia mengatakan bahwa pendidikan Islam yang integral tidak mengenal adanya pemisahan antara sains dan agama. Usaha Natsir untuk mengintegrasikan system pendidikan Islam direalisasikan dengan mendirikan lembaga pendidikan Islam, yang menyatukan dua kurikulum, yaitu antara kurikulum sekolah tradisional yang banyak memuat pelajaran agama dan sekolah barat yang memuat pelajaran-pelajaran umum. ${ }^{13}$

Jika pendidikan formal dalam hal ini sekolah dasar, dan pesantren dapat di integrasikan kedalam konteks yang yang integral, maka model atau sistem pendidikannya akan menjadi alternatif pengembangan pendidikan formal di Indonesia. Kemudian muncul pertanyaan, nilai-nilai apa saja yang dapat diambil dari pesantren, kemudian dibumikan dalam tradisi pendidikan formal sekolah dasar? Dalam hal ini lembaga pesantren difungsikan untuk membangun tradisi yang kokoh. Tradisi yang dimaksudkan adalah kebiasaan atau adat istiadat yang bernuansa Islam. Misalnya, kebiasaan melakukan shalat berjamaah, tadarrus al-Qur'an, qiyamul lail, menghargai waktu, disiplin, menghormati sesama.

Pendidikan formal dan pesantren sebagai penangkal pribadi bangsa terhadap dampak-dampak kemajuan IPTEK saat ini, akan tetapi lebih dari itu pendidikan harus kontekstual, fungsional, dan aktual dalam pembinaan watak dan sikap bangsa (Character

${ }^{10}$ Haidar Putra Daulay, Sejarah Pertumbuhan dan Pembaharuan Pendidikan Islam di Indonesia, (Jakarta: Putra Grafika, 2007), 21

${ }^{11}$ Lihat dalam A. Fattah Yasin, Dimensi-Dimensi Pendidikan Islam, 240

12 Tim penyususn ensiklopedi nasional Indonesia, jilid 7 (Jakarta pt cipta adi pustaka,1989),189.

${ }^{13}$ Abudin nata,dkk. Integrasi ilmu agama dan ilmu umum (Jakarta: raja grafindo persada 2005),149. 
Building). Saat ini sudah sering sekali anak-anak SD prilakunya banyak yang sudah tidak wajar karena hari ini kita hidup di masa digital. Pembangunan karakter khusunya khususnya di tingkat dasar harus terus dilakukukan, karena merekalah yang akan melanjutkan kepemimpinan. Sedangkan maksud integrasi pesantren dalam tulisan ini adalah, mengintegrasikan beberapa komponen yang ada dalam dunia pesantren ke dalam pendidikan umum, seperti program pembiasaan shalat berjamaah dan shalat dhuha, di terapkan di sekolah-sekolah dasar negeri yang mayoritas daerahnya beragama islam. Di SDN SDN seluruh Indonesia, porsi mata pelajaran PAI sangat sedikit sekali dan itu kalau tidak disertai dengan pembiasaan akan susah sekali dalam penerapan kehidupan seharisehari. Kecuali memang anak tersebut berada di lingkungan yang tepat seperti lingkungan keluarga yang religious dan sangat sadar bahwa pendidikan agama itu sangat penting

\section{Nilai-Nilai Dalam Dunia Pesantren Yang Perlu Di Terapkan Di Sekolah Dasar}

Ada beberapa nilai-nilai di lingkungan pesantren yang sangat perlu di terapkan untuk anak-anak di sekolah dasar atau sekolah formal yaitu:

a. Nilai pendidikan I'tiqadiyah.

Nilai pendidikan I'tiqadiyah. ini merupakan nilai yang terkait dengan keimanan seperti iman kepada Allah swt, malaikat, rasul, kitab, hari akhir dan takdir yang bertujuan menata kepercayaan individu. Iman berasal dari bahasa Arab dengan kata dasar amana yu'minu imanan artinya beriman atau percaya. ${ }^{14}$ Bukti-bukti keimanan diantaranya: a) Mencintai Allah swt dan Rasul-Nya. b) Melaksanakan perintahperintah-Nya c) Menghindari larangan-larangan-Nya. d) Berpegang teguh kepada Allah swt dan sunnah Rasul-Nya. e) Membina hubungan kepada Allah swt dan sesama manusia. f) Mengerjakan dan meningkatkan amal saleh. g) Berjihad dan dakwah. Nilai Kemanusiaan.

b. Nilai Pendidikan Amaliyah.

Nilai pendidikan amaliyah merupakan nilai yang berkaitan dengan tingkah laku. Nilai pendidikan amaliyah di antaranya: Pendidikan Ibadah, Ibadah merupakan bukti nyata bagi seorang muslim dalam meyakini dan mengimani aqidah Islamiyah. Pembinaan ketaatan untuk beribadah anak-anak kepada Allah dimulai dari dalam

\footnotetext{
${ }^{14}$ Ahmad Tafsir, Ilmu Pendidikan dan Perspektif Islam, 93
} 
keluarga dan sejak dalam kandungan. Sejak dini anak-anak harus diperkenalkan dengan suara-suara ayat suci al-Qur'an. nilai ibadah, seperti diajarkan melafalkan surat-surat pendek dari Al-Qur'an untuk melatih lafal-lafal agar fasih mengucapkannya, karena membaca Al-Qur'an adalah ibadah. Kemudian juga anakanak dilatih mendirikan shalat, maksudnya ialah agar ketika anak mulai baligh, tidak perlu bersusah payah belajar shalat.

c. Nilai Pendidikan Khuluqiyah

Pendidikan khuluqiyah ini merupakan pendidikan yang berkaitan dengan etika (akhlak) yang bertujuan membersihkan diri dari perilaku rendah dan menghiasi diri dengan perilaku terpuji. Pendidikan akhlak dalam penerapan di sekolah hari ini, sering di sebut dengan pendidikan karakter, sekolah hari ini selalu mendambakan sekolah yang berkarakter. Secara etimologi, istilah karakter berasal dari bahasa latin character, yang berarti watak, tabiat, sifat-sifat kejiwaan, budi pekerti, kepribadian dan akhlak. Sedangkan secara terminologi (istilah), karakter diartikan sebagai sifat manusia, manusia pada umumnya yang bergantung pada faktor kehidupannya sendiri. Karakter adalah sifat kejiwaan, akhlak, atau pekarti yang menjadi ciri khas seseorang atau sekelompok orang. Karakter merupakan nilai-nilai perilaku manusia yang berhubungan dengan Tuhan Yang Maha Esa, diri sendiri, lingkungan dan kebangsaan yang terwujud dalam pikiran, sikap, perasaan, perkataan, dan perbuatan berdasarkan norma-norma agama, hukum tatakrama ${ }^{15}$

Karakter sesorang dalam proses perkembangan dan pembentukannya dipengaruhi oleh dua faktor yaitu factor lingkungan (nurture), dan factor bawaan (nature). Karakter seseorang dalam proses perkembangan dan pembentukannya dipengaruhi oleh dua faktor bawaan (nature), sedangkan seorang yang berkarakter menurut pandangan agama, pada dirinya terkandung pada potensi-potensi yaitu: sidik, amanah, fatanah, dan tablig, karakter menurut teori pendidikan yaitu: apabila sseorang memiliki potensi kognitif, afektif, dan pasikomotor yang teraktualisasi dalam kehidupannya. Adapun menurut teori-teori social seseorang yang berkarakter

\footnotetext{
${ }^{15}$ Agus Zainul Fitri, Pendidikan Krakter Berbasis Nilai \& Etika di Sekolah (Jakarta: Ar-Ruzz Media, 2012), 20.
} 
mempunyai logika dan rasa dalam hubungan intrapersonal dan interpersonal dalam kehidupan bermasyarakat. ${ }^{16}$

Pembentukan karakter seharusnya dimulai sejak saat anak masih kecil, membentuk karakter merupakan proses yang berlangsung seumur hidup. Anak-anak akan tumbuh menjadi pribadi yang berkarakter jika ia tumbuh pada lingkungan yang berkarakter pula. Dengan begitu fitrah sebagai anak yang dilahirkan suci. Berkembang secara optimal. sehingga ada tiga pihak yang berperan penting dalam membentuk karakter anak yaitu: keluarga, sekolah, dan masyarakat. Dalam pembentukan karakter ada dua hal yang belangsung antara lain:

a. Anak mengerti baik dan buruk, yaitu mengerti tindakan apa yang harus diambil, mampu memberikan prioritas hal-hal yang baik. Mempunyai cinta kebajikan, dan membenci perbuatan buruk. Kecintaan ini merupakan obor atau semangat untuk berbuat kebaikan. Misalnya anak tak mau berbohong," kerena tahu bohong itu buruk. Ya tidak mau melakukannya karena mencintai kebaikan.

b. Anak mampu melakukan kebajikan, dan terbiasa melakukan lewat proses itu, beberapa karakter yang penting ditanamkan pada anak yakni: Cinta kepada Tuhan dan alam semesta beserta isinya, tanggung jawab, kedisplinan, kemandirian, kejujuran, hormat dan santun, kasih sayang, kepedulian dan kerja sama, percaya diri, kreatif, kerja keras, keadilan dan kepemimpinan, baik dan rendah hati, toleransi, cinta damai dan persatuan. ${ }^{17}$

\section{Metode pesantren dalam membentuk karakter yang bisa di aplikasikan di lembaga formal (Sekolah Dasar)}

Setidaknya ada 6 metode yang diterapkan dalam membentuk karakter santri, yakni:

1. Metode Keteladanan ${ }^{18}$

Secara psikologis, manusia sangat memerlukan keteladanan untuk mengembangkan sifat-sifat dan petensinya. Pendidikan perilaku yaitu pendidikan

\footnotetext{
${ }^{16}$ Novan Ardy Wiyani, Manajemen Pendidikan Karakter (Yogyakarta: Pustaka Insan Madani, 2012), 46.

${ }^{17}$ Sofan Amri dkk, Implementasi Pendidikan karakter (Jakarta: Prestasi Pustaka, 2011), 102-103

${ }^{18}$ Mukti Ali menyebutkan bahwa pendidikan terbaik ada di pesantren, sedang pengajaran terbaik ada di sekolah/madrasah. Lihat Zuhdy Mukhdar, KH. Ali Ma'shum Perjuangan dan Pemikirannya, (Yogyakarta, tnp, 1989)
} 
dengan cara memberikan contoh-contoh yang kongkrit bagi para santri. Dalam pesantren, pemberian contoh keteladanan sangat ditekankan. Kiai dan ustadz harus senantiasa memberikan uswah yang baik bagi para santri, dalam ibadah-ibadah ritual, kehidupan sehari-hari maupun yang lain, karena nilai mereka ditentukan dari aktualisasinya terhadap apa yang disampaikan. Semakin konsekuen seorang kiai atau ustadz menjaga tingkah lakunya, semakin didengar ajarannya. Menurut ahmad tafsir sebagaimana yang di jelaskan dalam bukunya ilmu pendidikan dalam perspektif Islam, dijelaskan bahwa syarat seorang pendidik dalam Islam adalah berkesusilan, syarat ini sangat penting yang harus dimiliki seorang pengajar, baik di pesantren ataupun di sekolah formal. ${ }^{19}$

2. Metode latihan dan Pembiasaan

Mendidik perilaku dengan latihan dan pembiaasaan adalah mendidik dengan cara memberikan latihan-latihan terhadap norma-norma kemudian membiasakan santri untuk melakukannya. Dalam pendidikan di pesantren metode ini biasanya akan diterapkan pada ibadah-ibadah amaliyah, seperti shalat berjamaah, kesopanan pada kiai dan ustadz. Pergaulan dengan sesama santri dan sejenisnya. Sedemikian, sehingga tidak asing di pesantren dijumpai, bagaimana santri sangat hormat pada ustadz dan kakak-kakak seniornya dan begitu santunnya pada adik-adik pada junior, mereka memang dilatih dan dibaisakan untuk bertindak demikian

3. Metode Mengambil Pelajaran (Ibrah)

Secara sederhana, ibrah berarti merenungkan dan memikirkan, dalam arti umum bisanya dimaknakan dengan mengambil pelajaran dari setiap peristiwa. Abd. Rahman Al-Nahlawi, seorang tokoh pendidikan asal timur tengah, mendefisikan ibrah dengan suatu kondisi psikis yang manyampaikan manusia untuk mengetahui intisari suatu perkara yang disaksikan, diperhatikan, diinduksikan, ditimbang-timbang, diukur dan diputuskan secara nalar, sehingga kesimpulannya dapam mempengaruhi hati untuk tunduk kepadanya, lalu mendorongnya kepada perilaku yang sesuai. ${ }^{20}$

\footnotetext{
${ }^{19}$ Ahmad Tafsir, Ilmu Pendidikan Dalam Perspektif Islam(Bandung: PT Remaja Rosdakarya, 1994)cet ke 2 hal 46.

${ }^{20}$ Abd. Rahman an Nahlawi, Prinsip-Prinsip dan Metode Pendidikan Islam, diterjemahkan Dahlan \& Sulaiman, (Bandung: Dipenegoro, 1992), 390
} 
4. Metode Nasehat .

Menasehati santri hampir setiap hari dilakukan oleh para kyai, dan metode tersebut selalu ada di pesantren. Kyai menasehati biasanya selepas ngaji, selepas sholat.

5. Mendidik melalui Kemandirian

Kemandirian tingkah-laku adalah kemampuan santri untuk mengambil dan melaksanakan keputusan secara bebas. Proses pengambilan dan pelaksanaan keputusan santri yang biasa berlangsung di pesantren dapat dikategorikan menjadi dua, yaitu keputusan yang bersifat penting-monumental dan keputusan yang bersifat harian. Pada tulisan ini, keputusan yang dimaksud adalah keputusan yang bersifat rutinitas harian

6. Metode Kedisiplinan

Dalam ilmu pendidikan, kedisiplinan dikenal sebagai cara menjaga kelangsungan kegiatan pendidikan. Metode ini identik dengan pemberian hukuman atau sangsi. Tujuannya untuk menumbuhkan kesadaran siswa bahwa apa yang dilakukan tersebut tidak benar, sehingga ia tidak mengulanginya lagi. ${ }^{21}$ Kedisiplinan $^{2}$ dilakukan oleh kiai sehingga santri merasa ada keadilan dan bisa meniru sikap kiai dalam menjalankannya. Yang menarik dari konsep ta'dib ini adalah timbulnya rasa malu dan sungkan dari para santri ketika melanggar peraturan. Rasa malu dan sungkan ini awalnya berasal dari faktor psikis yang tidak nyaman ketika diolok-olok atau dilihat oleh santri lainnya karena telah melanggar peraturan.

7. Metode pujian dan hukuman

sangat perlu diterapkan, karena dengan dipuji atau dengan hukuman yang mendidik, akan membuat anak agar lebih bersemangat lagi.

\section{Kesimpulan}

Pendidikan formal dan dan non formal (pesantren) adalah dua lembaga pendidikan yang mempunyai banyak perbedaan. Pendidikan umum. Misalnya, SD (Sekolah Dasar) mempunyai keunggulan dari segi rasionalitas dan eksperimentas, sedangkan pondok pesantren mempunyai keunggulan di bidang kebiasaan yaitu akhlak

\footnotetext{
${ }^{21}$ Hadari Nawawi, Pendidikan dalam Islam, (Surabaya: Al-Ikhlas: 1993), 234
} 
yang nomer 1, Karena seseorang yang berilmu itu harus beradab. Hari ini semua pendidikan selalu menggembar gemborkan pendidikan yang berkarakter. Sejatinya pendidikan berkarakter itu sudah di ajarkan sejak dini di dunia pesantren. Jadi pesantrenpesantren anak, ataupun madrasah-madrasah diniyah yang ada di pondok pesantren, selalu menomer satukan akhlak atau karakter. Banyak sekali metode-metode di pesantren yang perlu di terapkan di SD (sekolah dasar). Dan sangat bagus ketika sebuah sekolah dasar bisa berintegrasi dengan pondok pesantren. Misal SD negeri sudah memulai memberikan praktek shalat dhuhur berjamaah, yang memberikan dan membiasakan mendidik akhlak bukan hanya guru agama saja, tetapi juga tugas bersama semua yang ada di sekolah. Pembentukan karakter seharusnya dimulai sejak saat anak masih kecil, membentuk karakter merupakan proses yang berlangsung seumur hidup. Anak-anak akan tumbuh menjadi pribadi yang berkarakter jika ia tumbuh pada lingkungan yang berkarakter pula. Dengan begitu fitrah sebagai anak yang dilahirkan suci. Berkembang secara maksimal.

\section{Daftar Pustaka}

Abudinnata, dkk. Integrasi Ilmu Agama Dan Ilmu Umum, Jakarta: Raja Grafindo Persada 2005

Amri, Sofan dkk, Implementasi Pendidikan Karakter, Jakarta: Prestasi Pustaka, 2011 An Nahlawi, Abd. Rahman, Prinsip-Prinsip dan Metode Pendidikan Islam, diterjemahkan Dahlan \& Sulaiman, Bandung: Dipenegoro, 1992

Asrohah, Hanun. Kelembagaan Pesantren Asal-Usul Dan Perkembangan Pesantren Jawa, Jakarta; Bagian proyek peningkatan informasi penelitian dan diklat keagamaan, 2004

Azra, Azyumardi. Pendidikan Islam: Tradisi Dan Modernisasi Menuju Millenium Baru, Jakarta: Logos, 2002.

Barizi, Ahmad (ed), Holistik Pemikiran Pendidikan Malik Fadjar, Jakarta: Raja Grafindo Persada, 2005.

Bruinessen, Martin Van. Kitab Kuning: Pesantren dan Tarekat, Bandung: Pustaka 1995.

Daulay, Putra Haidar. Sejarah Pertumbuhan dan Pembaharuan Pendidikan Islam di Indonesia, Jakarta: Putra Grafika, 2007

Dhofier, Zamakhsari.Tradisi Pesantren, Study Tentang Pandangan Hidup Kyai, Jakarta: LP3ES, 1982.

Fitri, Agus Zainul. Pendidikan Krakter Berbasis Nilai \& Etika di Sekolah, Jakarta: ArRuzz Media, 2012. 
Madjid, Nur cholis. Bilik-Bilik Pesantren Sebuah Potret Perjalanan, Jakarta: Mizan Paramadina, 1988.

Nawawi, Hadari. Pendidikan dalam Islam, Surabaya: Al-Ikhlas: 199

Tafsir, Ahhmad. Ilmu Pendidikan Dalam Perspektif Islam,Bandung: PT Remaja Rosdakarya, 1994

Tim Penyusunh Ensiklopedi Nasional Indonesia, jilid 7 , Jakartah: PT Cipta Adi Pustaka,1989.

Wahid, Abdurrahman. “ Asal Usul Tradisi Keilmuan Di Pesantren” Jurnal Pesantren (Oktober-Desember 1984)

Wiyani, Novan Ardy. Manajemen Pendidikan Karakter,Yogyakarta: Pustaka Insan Madani, 2012

Zuhdy Mukhdar, KH. Ali Ma'shum Perjuangan dan Pemikirannya, Yogyakarta, Tnp,1989 